\title{
SUPPORT FOR THE PROCESS OF SOCIAL ADAPTATION OF STUDENTS WITH SPECIAL EDUCATIONAL NEEDS
}

\author{
Danuta Marzec \\ Akademia im. Jana Długosza w Częstochowie, Polska
}

\begin{abstract}
The most recent tendencies in teaching children with developmental deficits advocate using inclusive educations which allow for an optimization of the process of social adaptation. Rehabilitation programs to support these children are an integral part of individual educational programs which are developed for each student and based on the positive diagnosis that accentuates child's strengths. The process of social adaptation of a child with disability starts in families and is continued in nursery schools and schools. Lessons at schools and extra-curricular classes open up opportunities for starting interpersonal contacts that play a fundamental role in the process of social adaptation. The particular importance can be from physical activity and various forms of physical recreation. The support for the development and process of social adaptation through various forms of physical activity results from the natural needs of a child. The questionnaire survey conducted among parents and teachers demonstrated that the respondents realize the importance of physical activity in the process of social development of children with developmental dysfunctions.
\end{abstract}

Keywords: adaptation, inclusive education, physical activity, recreation, sport, special needs, school, family.

\section{Introduction}

Recent several years have seen a substantial interest of the pedagogical, medical and ethical environments, with particular focus on parents, attracted to the initiatives aimed at supporting the development and providing equal educational opportunities for children with developmental difficulties and dysfunctions. This group of children is substantially varied in terms of the depth and extent of disturbances, but all of them are prone to the difficulties with sufficient development, abilities to familiarize with the world and adapt to social requirements.

Children and young people with special developmental and educational needs include those with symptoms that make it difficult or prevent from development of motor, sensory, cognitive, communicational, emotional, social and psychical functions that have an effect on the quality of life and social 
adaptation. Modern education should be adjusted to the needs of this group of students and oriented towards finding individual opportunities and barriers to the process of social adaptation. (Zaremba, 2014). Social adaptation results from a long-term process of learning conceptual skills (learning the language, reading, writing, self-control, concept of cash), social skills (responsibility, respecting the principles of social and legal interactions, self-assessment, interpersonal skills) and practical skills (life-related and professional skills, self-care, safety) which should be learnt in order to function properly in everyday life (AAMR, American Association on Mental Retardation, 2001). People with disability are often unable to learn all adaptive skills areas, thus needing the systems of support (D. Deutsch Smith, 2008). They should receive the support from schools, families and local environments.

The approach to educating children with developmental dysfunctions in Poland is twofold. Besides special schools with curricula adjusted to the specific types of disorders, integration classes and divisions in public institutions, a new organizational solution is provided by inclusive (open) teaching, which consists in education of these children in public schools for healthy children. Obviously, this requires greater financial, organizational and modern pedagogical solutions but prevents from stigmatization and marginalization, thereby opening up the opportunities for acquiring greater social competencies. The researchers in the field of integration and inclusion problems emphasize that this process leads to many changes at individual and general social levels while raising the awareness and changing social attitudes (Zacharek, 2011). This problem seems to be even more important assuming that the most essential task of the modern educational system is to meet educational needs of all children. Analysis of the problems of equal opportunities seems to be important given that the risk of marginalization and social exclusion are not reducing in modern societies, which is connected with substantial socio-cultural differentiation among citizens. Contemporary school has to accept and appreciate differences between people, adopt the approach of social model of disability and determine environmental barriers concerning the strategy of support for the process of social adaptation in different environments. It is also necessary to ensure "close cooperation with parents or legal guardians of a child and also tailor the pedagogical and educational programs to these people" (Karpuszenko, 2008).

The data presented by the Central Statistical Office of Poland show that the number of disabled children aged from 0 to 15 years accounts for $13 \%$ of the general population, with higher number of boys from bigger cities $(58.3 \%$ living in cities compared to $41.7 \%$ in rural areas). Greater percentage of people with dysfunctions was found in older children. Some $80 \%$ of children had one dysfunction while others had two or more. According to the definition adopted by the Central Statistical Office of Poland, the disabled children are those with 
current medical certificate of disability and those who, without such a legal statement, experience limitations in performing basic activities compared to their peers.

The focus of the study was on selected forms of support for physical and social development of children which are used in schools, family and local environments, with particular focus on motor and recreation activities. The questionnaire survey conducted among parents and teachers concerned their opinions about the effect of motor and recreational activity and sports on the process of learning independence by children and young people and their social adaptation.

\section{Social adaptation of students with special educational needs and its determinants}

The overriding objective of educational activities is child's adaptation to the social environment. Adaptive competencies are acquired for the whole life. However, the first experiences connected with starting the education are critical. This is particularly important with respect to children with limited abilities and reduced level of functioning, who have greater problems with adjustment to the environment. Adaptation means a dynamic process of changes occurring in the behaviour and emotions of a child and its environment. It consists in stimulation of the harmony between the needs and activities of a person and the requirements and expectations of the environment (Kupisiewicz \& Kupisiewicz 2009).

The basis for adaptation is incessant interaction between the individual and his or her environment, leading to the transformation of the structure of the person (child) to meet the requirements of the environment, and the transformation of the environment and its adjustment to the internal structure of the entity.

In the process of adaptation, psychologists distinguish between several stages:

- psychological reorientation, i.e. learning new behavioural patterns and using them in practice,

- tolerance, meaning respect for others' views, beliefs and tastes,

- assimilation means total adjustment of a person to current conditions.

Through adaptation, humans meet their needs and are better prepared for living in society (Smolski et al., 1999).

Social adaptation is affected by such factors as age, gender, development of the nervous system, psychophysical development, temperament, intelligence, knowledge of your own strengths, independence, responsibility and association 
to the group. Children with disabilities experience certain adaptive difficulties connected with immaturity or disturbances in the function of the central nervous system, emotional disturbances and deficits in orientation and cognitive (perception, attention, memory) and intellectual processes. Slower development of speech, limited communication and low level of self-care abilities have a negative effect on the processes of social adaptation and cognitive development. Furthermore, they can also lead to lower interest in the world while difficulties with spatial orientation may increase fear and lack of sense of security (Gruszczyk-Kaczyńska \& Zielińska, 2000). Lower resistance of human body, illnesses and isolation make the adaptation process even more difficult.

The principal effect on the process of adaptation of children with disabilities is from family environment, previous experiences and the environment where adaptation occurs (nursery school, school, peer group). The important factor in the development of adaptation abilities in families is ties between the child and his or her parents that ensure the sense of safety and represents the basis for further socialization. Parenting styles have also a considerable effect on adaptive abilities. If parents are inconsistent, overprotective, excessively liberal or rigorous and they do not ensure the feeling of security and consistency, the adaptive process is much more difficult (Gołaska, 2013).

The principal process of social adaptation occurs in the peer group in intentional educational environments, such as nursery schools and schools.

In Poland, inclusive education is preferred with respect to children with developmental deficits, thus allowing them to learn in general education environments and local schools which are located nearby their family homes. This is the most convenient solution from the standpoint of social adaptation and peer integration. Inclusive education means learning according to a general education program and using the same educational paths based on similar contents with adequate modifications and individual approach to the child. Inclusive learning is a continuous process, which is aimed at reaching a high quality of education of all children, especially those who are threatened with exclusion through the use of updated and modified teaching methodologies (European Agency for Development, 2009).

The legal context concerning inclusive education was presented in the UNESCO document, which emphasized variety of educational needs of all children, the need for living in local society and elimination of any forms of discrimination (UNESCO 2009).

The class with a child with disability should represent a group which is internally differentiated in terms of socio-economic and mental development, which has a positive effect on individual development of students and their accepting the dysfunctions as one of many traits they have. The major emphasis 
should be on strengths of the child which help them be successful, thus increasing their self-assessment and self-esteem. Therefore, the particular role is assigned to teachers and therapists (Gil, 2009) who should support students in finding their personal potential, build good relations and friendly atmosphere in the class. The relations between teachers and students can be conducive to revealing student's difficulties or aptitudes and should be viewed as an opportunity for implementation of supportive actions which should be taken according to a specific order:

- noticing and initial definition of difficulties (multi-expert evaluation of the level of functioning of a student),

- determination of the educational needs of the child,

- preparation of an individual educational and therapeutic program (IPET),

- implementation of actions and measures,

- $\quad$ evaluation of the effectiveness of the actions (Dotka, Kazimierczak et al., 2009)

The IPET program discusses the scope of adjustment of the educational requirements contained in curricula to individual developmental needs and psychophysical abilities of a student, type and scope of integrated activities of teachers and experts.

Providing adequate conditions for education and adaptation includes in particular:

- adjustment of the method to communicate with students,

- elongation of work time necessary for a student to perform tasks,

- division of the learning material into smaller parts, reduction in the number of tasks to be performed and higher number of material repetitions,

- frequent reference to reality i.e. using the reference methodologies that allow for multisensory cognition and the alternate use of the expository and activation methods,

- adjustment of the number of stimuli connected with the educational process, e.g. in children with ADHD or autistic children, such that they are not excessively frequent,

- the use of additional didactic and technical resources,

- $\quad$ the use of individual assessment of students (J. Gładkowska 2010).

Students with special educational needs in the system of open (inclusive) education need additional support in the form of special classes focused on correction, compensation, speech therapy, rehabilitation and social therapy.

In order for the process of adaptation to the peer environment to be effective, the conditions that help students be more successful and improve their self-assessment should be provided. 
The best opportunity to start and maintain social contacts is extra-curricular classes adapted to the people with different adaptive abilities, especially classes focused on sport and recreation.

\section{Sport and recreation activity in the process of social adaptation of children with developmental limitations}

Adaptive factors are understood to mean the stimuli used to ensure best adjustment of the person possible to the changing conditions of living, physical, natural (temperature, atmospheric pressure, air humidity), social and civilization environments as well as to physical exercise and overcoming difficulties. The successful effects of adaptation depend on the intensity of stimuli that cause specific adjustment changes. The adaptive stimuli which are adjusted to human tolerance limits have a beneficial effect, whereas the stimuli that exceed these limits can be the reason for disturbances in functional balance of the body.

The sport and recreation classes represent the perfect opportunity for adaptation to the social environment for children and young people with different developmental potential. Social attitudes are best developed through teamwork, practising with a partner, collaboration and competition. Movementbased games and playing limit the selfishness and egocentricity since performing a task requires respecting specific rules and principles (J. Bielski 2005).

Modern rehabilitation concepts assume inclusion of the people with developmental deficits in social life, which results from humanitarian and ethical reasons. Since the objective of rehabilitation and, consequently, social adaptation is to improve the disturbed functions of human body, the controlled movement seems to be critical. The movement can be ensured by various forms of participation in the physical culture connected with physical education, sport, tourism and forms of treatment (motor rehabilitation). Physical recreation contributes to the development of personality, interests, elevates activity, relieves tension, prevents from hypokinesis, and improves resistance and mood.

Sport performs stimulating, adaptive, compensatory, informational, patterncreating, hedonistic and recreational functions. Physical activity increases selfesteem, supports people in their believing in his or her strength, instils persistence and consistency in actions, allows for integration in the group, improves emotional health, satisfies the need for security, supports social development and prevents from risky behaviours (A. Marzec 2008).

Sport can be used for education and adaptation that integrates all the environments of children and young people, allows for familiarizing with the student and paves the way for other methods of educational effect. 
Sport activities for children and young people organized at school and local environments must be adjusted to individual abilities according to the rehabilitation program while maintaining its entertaining character. They have to be safe, limit the risk of accidents and injuries, consistent with regulations and rules and realistic planning of training sessions. They should be easily available and adjusted to the abilities of all the disabled people who want to participate in sport classes.

Sport for disabled people offers opportunities for self-realization, overcoming their own weaknesses and loneliness and, first and foremost, adaptation and social integration. From the standpoint of the biological and health-related needs, the need for physical exercise seems to be obvious. Regular physical activity is one of the major components of healthy lifestyles and an element of health education.

Physical exercise is a stimulating factor in the process of adaptation, encourages people to be active and start contacts. The utilitarian aspect of physical exercises and playing is also important since they help extend and improve the activities and motor habits in everyday life and improve the level of adaptive and socially useful abilities. Physical activity and sport are essential for the development of social attitudes, performing the functions resulting from social needs and they rise social awareness and show young people how to spend their leisure time.

Sport, games and playing based on physical exercise help children start contacts with their guardians who are older and more experienced as well as with peers and establish social ties based on affection, empathy, consideration and goodwill.

There are a number of examples that demonstrate that sport can positively change lives of people with disabilities, challenge the stereotypes, contribute to better social adaptation and integration between generations.

The questionnaire survey conducted among parents $(\mathrm{N}=62)$ and teachers $(\mathrm{N}=35)$ of children with developmental difficulties asked the respondents about "What are the benefits of common education of children with disability and their healthy peers?". Most of parents $(91 \%)$ and teachers $(83 \%)$ answered that inclusive teaching is the best form of education since children with dysfunctions are not isolated $(\mathrm{R}=72 \%, \mathrm{~W}=86 \%)$, can familiarize with each other $(64 \%$, $47 \%)$, better adjust to future life $(74 \%, 51 \%)$, and can observe and learn from healthy peers $(52 \%, 48 \%)$, participate together in organized extra-curricular classes $(49 \%, 38 \%)$ and learn rules of living in a community $(52 \%, 48 \%)$.

It can be noticed that the most of the answers emphasized the adaptive and integration values of open teaching and the parents were more positive about this form of education. 
With regard to the question "Which forms of activity are the most beneficial from the standpoint of the process of social adaptation and peer integration?", the answers were as follows (multiple-choice options):

- $\quad$ games and playing based on physical exercise $(83 \%, 79 \%)$

- $\quad$ sport classes $(76 \%, 59 \%)$

- $\quad$ ball games, volleyball $(56 \%, 64 \%)$

- $\quad$ hiking and bus trips (43\%, $51 \%)$

- $\quad$ movement and dancing classes $(29 \%, 33 \%)$

- Classes in a classroom $(17 \%, 28 \%)$

- $\quad$ arts classes $(8 \%, 15 \%)$

- $\quad$ billiard $(2 \%, 4 \%)$

- $\quad$ cycling $(1 \%,-)$

- $\quad$ swimming $(-, 2 \%)$.

The next question concerning the benefits of physical activity showed that the most parents and teachers realize the health and adaptation values of sports and recreation classes and they responded that these classes: improve health and physical fitness ( $86 \%, 87 \%)$, improve mood and give happiness $(79 \%, 80 \%)$, help develop interests $(22 \%, 60 \%)$, integrate the group (66\%, $71 \%)$, instil resourcefulness $(55 \%, 64 \%)$, facilitate mental processes $(5 \%, 49 \%)$, teach how to spend leisure time $(47 \%, 39 \%)$, offer opportunities for relieving tension $(26 \%, 13 \%)$, teach discipline, diligence and tolerance $(25 \%, 17 \%)$, teach healthy competition $(7 \%, 9 \%)$, offer opportunities for trips $(4 \%,-)$, help receive rewards $(2 \%,-)$.

\section{Conclusions}

- The most of parents want their disabled children to learn with healthy peers as close to their family homes as possible in their local environments. They claim that this helps them adapt to life through participation in classes and extra-curricular classes with healthy children. The views of parents and teachers about inclusive education are similar, although teachers expressed more doubts about this organizational form. This may result from their experiences concerning organizational difficulties which are connected with this form of education. Participation of a child with disability in classes is connected with additional duties of teachers who implement teaching programs based on the individual educational and therapeutic programs (IPETs) and are obliged to cooperate with other specialists.

- Parents and teachers agree that the best form that stimulates social adaptation is physical activity i.e. games and playing connected with physical exercise, sport, team games and trips. Less important factors include didactic classes, arts and music. 
- All the respondents realize the importance of physical activity in the process of adaptation and social integration. They emphasize first and foremost health benefits (improved health status and psychophysical fitness), relax and entertainment (source of happiness and improved mood) and opportunities for development of personality traits (diligence, persistence, discipline and competition).

- Teachers emphasize more often the general development benefits of physical activity that allow students to actively relax and facilitation of mental processes such as perception, attention, memory, concrete and visual thinking, cause-and-effect thinking, development of interests, development of habits of polite behaviour in the group, development of independence and abilities to cope with new situations.

\section{References}

Bielski, J. (2005). Metodyka wychowania fizycznego, Kraków pp. 15 - 20

Deutsch Smith D. (2008). Pedagogika specjalna vol. I (eds. ) A. Firkawska - Mankiewicz, G. Szumski, Warsaw p. 225

Dotka, M., Kazimierczak, M. et al. (2009). Model pomocy psychologiczno - pedagogicznej, w szkole $i$ wspótpracy pomiędzy szkota i poradnia - założenia -

Europen Agency form Development In Special Needdn Education (2009). Klasyczne zasady służące promocji jakości w edukacji włączającej - zalecenia dla decydentów-, Odense, De,nmark: Europejska Agencja Rozwoju Edukacji Uczniów ze Specjalnymi potrzebami, p. 14 and further

Gil, M. (2003). Kierunek edukacji włączającej w Kanadzie [in:] Czlowiek $z$ niepetnosprawnościa w przestrzeni spolecznej, Kraków p. 158 and further

Głodkowska, J. (2010). ed., Edukacja skuteczna, przyjazna i nowoczesna. Jak organizować edukację uczniów ze specjalnymi potrzebami edukacyjnymi, Warsaw.

Gołaska, P. (2013). Proces adaptacji społecznej dzieci z ograniczoną sprawnością, „Wychowanie w Przedszkolu”, February No. 2, Warsaw

Gruszacyk - Kolaczyńska, E., \& Zielińska, S. (2000). Płaczę i rozpaczam gdy musze iść do przedszkola - o kłopotach adaptacyjnych dzieci i o tym w jaki sposób można je zmniejszyć, ,Wychowanie w Przedszkolu” No. 10, Warsaw

GUS, (2015). J. Stańczyk, Gus. Departament Badań Demograficznych i Rynku Pracy, Warsaw, dzieci_w_polsce_w_2014_roku_charakterystyka_demograficzna.pdf

Karpuszenko, E. (2008). Zapobieganie zaburzeniom zachowania dzieci i młodzieży, [in:] A. Marzec (ed.), Funkcje opiekuńczo-wychowawcze wspótczesnej szkoły, Częstochowa, p. 186.

Kupisiewicz, Cz., \& Kupisiewicz, M. (2009). Stownik Pedagogiczny, Warsaw 2009

Marzec, A. (2008). Zajęcia sportowe i rekreacyjne jako metoda resocjalizacji [in:] Sport w resocjalizacji nieletnich, eds. E. Karpuszenko, A. Marzec, Częstochowa pp. 50-60

Smolski, R., Smolski, M., \& Stadtmüller, E. (1999). Stownik Encyklopedyczny Edukacji Obywatelskiej, p.16

UNESCO 2009, Policy Guidelines on Inclusion In Education, Paris: pp. 7 - 9, Warsaw

Zacharek, T. (2011). Edukacja włączająca szansą dla wszystkich uczniów, Mazowiecki Kwartalnik Edukacyjny, Meritum 1 (20), Warsaw. 
Danuta Marzec. Support for the Process of Social Adaptation of Students with Special Educational Needs

Zaremba, L. (2014). Specjalne potrzeby rozwojowe i edukacyjne dzieci i młodzieży. Identyfikacja SPR i SPE oraz sposoby ich zaspokajania, Warsaw pp. 7 - 10 